Fidei: Jurnal Teologi Sistematika dan Praktika, Vol. 3, No. 2, Des. 2020

\title{
Konsep Eduecologi dalam Pendidikan Agama Kristen Konteks Sekolah
}

\author{
Yosefo Gule \\ Universitas Quality Berastagi, Indonesia \\ Email: yosefogule@gmail.com
}

Diterima: 5 Oktober 2020

Direvisi: 2 Desember 2020

Disetujui: 17 Desember 2020

\begin{abstract}
Abstrak
Dalam tulisan ini, penulis akan mengkaji dan mendeskripsikan tentang konsep eduecologi dalam PAK konteks sekolah. Metode penelitian pada penulisan artikel ini adalah menggunakan metode kajian kualitatif-deskriptif dengan pendekatan library research, membaca dan membandingkan sejumlah referensi yang berhubungan dengan kajian. Pencegahan perusakan lingkungan hidup sejak dini sangatlah penting. Dalam hal ini PAK berwawasan lingkungan hidup merupakan wahana pembelajaran yang memfasilitasi peserta didik untuk mengenal Allah melalui karya ciptaanNya serta mewujudkan kedamaian di bumi melalui sikap hidup yang mengacu pada nilai-nilai eko-teosentris. Konsep eduecologi dalam PAK konteks sekolah dapat dilakukan melalui pengajaran pendidikan PAK dan fasilitas yang bias dimanfaatkan yaitu, melalui kegiatan belajar-mengajar PAK, lewat budaya sekolah, melalui kegiatan rutin di sekolah, keteladanan guru PAK, kegiatan spontan, pengkondisian lingkungan, lewat peran serta orang tua dari siswa dan peran serta gereja. Melalui PAK berwawasan lingkungan hidup, peserta didik diharapkan akan mengalami perjumpaan yang baik dan benar dengan Allah yang dikenal sebagai pencipta langit dan bumi, dipercaya dan diimaninya, serta dapat memaknai lingkungan hidup sebagai karya ciptaan Allah yang harus dikelola, dirawat dan dilestarikan Kata-Kata Kunci: Pendidikan Kristen; Pendidikan Lingkungan Hidup.
\end{abstract}




\section{Abstract}

In this paper, the author will examine and describe the concept of eduecology in the Christian Religious Education (CRE) school context. The research method in writing this article is to use a qualitative-descriptive study method with a library research approach, reading and comparing a number of references related to the study. Prevention of environmental destruction from an early age is very important. In this case, CRE with an environmental perspective is a vehicle for learning that facilitates students to know God through His creations and to create peace on earth through an attitude of life that refers to eco-theocentric values. The concept of eduecology in CRE in the school context can be carried out through CRE education teaching and facilities that can be utilized, namely, through CRE teaching and learning activities, through school culture, through routine activities at school, exemplary CRE teachers, spontaneous activities, environmental conditioning, through the participation of people. parents of students and church participation. Through the CRE with an environmental perspective, students are expected to have a good and true encounter with God who is known as the creator of heaven and earth, is trusted and believed in, and can interpret the environment as God's creation that must be managed, cared for and preserved.

Keywords: Christian Education; Environment Education.

\section{Pendahuluan}

Bumi yang merupakan bagian dari tempat tinggal manusia sedang mengalami kerusakan ekologi. Kerusakan ekologi yang terjadi saat ini memiliki dampak pada semua kehidupan di bumi, termasuk manusia di dalamnya. ${ }^{1}$ Dalam hal ini manusia bukan hanya sebagai korban dari dampak kerusakan ekologi, akan tetapi manusialah salah satu penyebab kerusakan ekologi. Persoalanpersoalan perusakan lingkungan hidup dan dampak yang terjadi bukanlah hal yang asing lagi di perbincangkan. ${ }^{2}$ Berdasarkan data laju pengurangan hutan di Indonesia sampai pada tahun 2005 mencapai 3,8 juta hektar pertahun atau setara 6 kali lapangan sepakbola/menit dan total kerusakan hutan 59,62 juta hektar dari 120,34 juta hektar luas hutan Indonesia. Ditambah lagi dengan bencana alam

\footnotetext{
${ }^{1}$ Hidayatus Sholihah and Lum'atun Nadzifah, "Aplikasi Pendidikan Lingkungan Hidup Bagi Anak Tingkat Sekolah Dasar Dalam Membentuk Kepedulian Anak Terhadap Lingkungan," Islamic Review : Jurnal Riset dan Kajian Keislaman 7, no. 2 (2018): 174-190.

${ }^{2}$ Amatus Woi, Menyapa Bumi Menyembah Hyang Ilahi, Dalam Buku "Manusia Dan Lingkungan Dalam Persekutuan Ciptaan” (Yogyakarta: Kanisius, 2008), 21
} 
seperti kebakaran hutan dan kekeringan. Data terakhir dari Dephut menyebutkan deforestasi seluas 1.089.560 hektar per tahun di tahun 2005. Sampai dengan tahun 2006, lahan kritis mencapai luas 77.806.880,78 hektar yang terbagi dalam: Sangat kritis seluas 47.610.080,86 hektar; Kritis seluas 23.306.233,01 hektar; dan agak kritis mencapai luas 6.890.566,91 hektar. ${ }^{3}$

Berdasarkan data Kementerian Lingkungan Hidup dan Kehutanan, Indonesia memproduksi sampah hingga 65 juta ton pada 2016, dan meningkat menjadi 67 ton pada 2017. Sementara itu, data Pusat Oceanografi LIPI menunjukkan, sekitar 35,15\% terumbu karang di Indonesia dalam kondisi tidak baik dan hanya $6,39 \%$ dalam kondisi yang sangat baik. Selain itu terjadinya pemanasan global yang dipicu karena pembakaran batu bara yang mencapai jumlah emisinya per tahun yaitu 9 miliar ton Co2; Adanya konversi lahan dan perusakan hutan dengan jumlah emisi mencapai 2,53 miliar ton Co2e; dan aktivitas dan pemakaian energy, pertanian dan limbah dengan emisi mencapai 451 juta ton Co2. Juga diperoleh data Korlantas Mabes Polri menyebutkan jumlah kendaraan yang terdaftar sampai 3 Januari 2017 mencapai 102.328.629 kendaraan. Kondisi ini menimbulkan munculnya masalah pencemaran udara. Data kematian akibat polusi udara mencapai lebih dari 165.000 orang. ${ }^{4}$ Data kebakaran hutan sampai tahun 2020 di seluruh Indonesia dari 34 Provinsi berjumlah 206 751,00 (ha). Persentase Desa menurut Jenis Pencemaran Lingkungan Hidup di seluruh Indonesia dari 34 Provinsi dari tahun 2014-2018: pencemaran air pada tahun 2014 10,69\% meningkat sampai tahun 2018 menjadi 25,11\%, pencemaran tanah pada Tahun 2014 1,58\% meningkat sampai tahun 2018 menjadi 2,69\% , pencemaran udara pada tahun 2014 14,60\% meningkat sampai tahun 2018 menjadi $11,83 \% .^{5}$

Sampai hari ini fenomena lingkungan hidup termasuk dalam keadaan kondisi krisis, baik itu krisis lingkungan fisik maupun lingkungan sosial. Indikasinya ialah keadaan lahan tanah pertanian semakin kurang produktif, flora dan fauna semakin punah yang disebabkan oleh eksploitasi sumber daya alam yang berlebihan dengan tidak mempertimbangkan daya dukung lingkungan. Dalam hal ini fenomena kerusakan lingkungan hidup seharusnya menyadarkan

${ }^{3}$ H. Abdul Karim, Manajemen Pendidikan Lingkungan Hidup Berbasis Partisipasi (Bandung: Kataba Group, 2018), 13

${ }^{4}$ Kalis Stevanus, "Pelestarian Alam Sebagai Perwujudan Mandat Pembangunan: Suatu Kajian Etis-Teologis," KURIOS: Jurnal Teologi dan Pendidikan Agama Kristen 5, no. 2 (2019): 94-108, http://www.sttpb.ac.id/ejournal/index.php/kurios/article/view/107/70.

${ }^{5}$ Krismawati, Nanik Supriyanai, and Chryssanti Widya, Statistika Lingkungan Hidup Indonesia 2020 (Jakarta: Badan Pusat Statistika, 2020), 240, 319. 
setia orang untuk mengoreksi tindakannya yang salah dalam berelasi dengan alam. Oleh sebab itu perlu usaha memperbaiki cara manusia dalam mengelola alam dengan bentuk tindakan baik pada tingkat kognitif, afektif, psikomotorik, maupun bersifat teoritis dan praktis. Bagaimanapun, narasi besar mengatakan bahwa persoalan lingkungan jelas berkaitan dengan watak manusia, terutama sebagai konsekuensi interaksi manusia dengan alam lingkungan. ${ }^{6}$

Melihat kondisi permasalahan aktual seperti itu, kita tidak dapat memungkiri bahwa lingkungan hidup merupakan bagian yang tak terpisahkan bagi kelangsungan makhluk hidup di bumi, termaksud di dalamnya adalah manusia, tumbuhan, hewan dan organisme lainnya yang memerlukan tempat tinggal. Untuk problema lingkungan agar tidak semakin akut, maka perlu langkah strategis dan berkesinambungan. Langkah yang dimaksud adalah melalui proses pendidikan berwawasan lingkungan hidup. ${ }^{7}$ Beberapa penelitian terdahulu yang telah dilakukan seperti Mulyana, ${ }^{8}$ Ahmad, ${ }^{9}$ Rezkita ${ }^{10}$ dan Karim ${ }^{11}$ mengatakan bahwa eduecologi merupakan salah satu upaya potensial dalam mengatasi krisis lingkungan yang terjadi saat ini dan di masa yang akan datang. Eduecologi yang disampaikan dilingkungan sekolah akan lebih efektif menyentuh dan melekat pada diri peserta didik. Penanaman kepedulian terhadap kelestarian sumberdaya alam dan lingkungan hidup di dilingkungan sekolah dapat dilakukan melalui proses belajar mengajar yang bermuatan PAK berwawasan lingkungan hidup, penyediaan lingkungan sekolah yang asri, dan ditunjang dengan fasilitas sekolah. PAK berwawasan lingkungan hidup di lingkungan sekolah merupakan modal dasar bagi pembentukan cinta lingkungan pada lintas generasi dalam perspektif kristiani.

Oleh sebab itu peranan pendidikan secara khusus Pendidikan Agama Kristen (selanjutnya akan disingkat PAK) sangat penting untuk mencegah kerusakan lingkungan hidup sejak dini. Dalam merekonstruksi pendidikan

${ }^{6}$ Firman Panjaitan, "MembangunTeologi Pertanian Melalui Pembacaan Lintas Tekstual Injil Matius Dan Kosmologi Jawa," Bonafide: Jurnal Teologi dan Pendidikan Kristen 1, no. 1 (2020): 44-64.

${ }^{7}$ M. Maghfur, "Pendidikan Lingkungan Hidup Dan Masa Depan Ekologi Manusia," Edukasia Islamika 8, no. 1 (2010): 57-71.

${ }^{8}$ Rachmat Mulyana, "Penanaman Etika Lingkungan Melalui Sekolah Perduli Dan Berbudaya Lingkungan," Jurnal Tabularasa PPS Unimed 6, no. 2 (2009): 175-180.

${ }^{9}$ Maghfur, "Pendidikan Lingkungan Hidup Dan Masa Depan Ekologi Manusia."

${ }^{10}$ Shanta Rezkita and Kristi Wardani, "Pengintegrasian Pendidikan Lingkungan Hidup Membentuk Karakter Peduli Lingkungan Di Sekolah Dasar," TRIHAYU: Jurnal Pendidikan KeSD-an 4, no. 2 (2018): 327-331.

${ }^{11}$ Karim, Manajemen Pendidikan Lingkungan Hidup Berbasis Partisipasi. 
agama Kristen berwawasan lingkungan hidup yang dapat disebut pendidikan transformasi yang menjadi tujuan adalah perubahan paradigma berpikir dalam bertindak dan ber-relasi dengan alam, manusia di bawa kedalam terang pemerintahan Allah yang menginginkan keadilan sehingga siap berjuang secara bebas dan bertanggung jawab demi perbaikan hidup. PAK berwawasan lingkungan hidup yang di ajarkan sejak dini menjadi solusi utama yang harus dilakukan agar generasi muda memiliki bekal pemahaman tentang lingkungan hidup secara Eko-Teosentris yang kokoh.

\section{Metode Penelitian}

Metode penelitian pada penulisan artikel ini adalah menggunakan metode kajian kualitatif deskriptif dengan pendekatan library research, membaca dan membandingkan sejumlah referensi ${ }^{12}$ yang berhubungan dengan konsep eduecologi dalam PAK konteks sekolah.

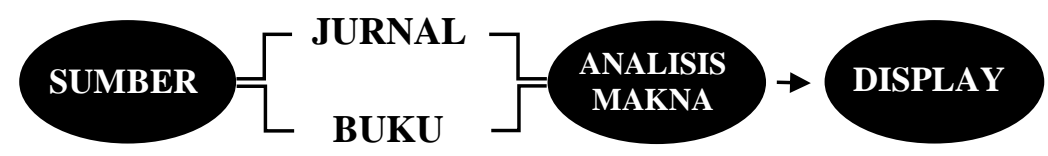

Gambar 1. Proses Penelitian

\section{Pembahasan dan Hasil}

\section{Konsep Eduecologi dalam Pendidikan Agama Kristen Konteks Sekolah}

Didalam setiap masing-masing fondasi pendidikan, ada dua sifat pengalaman belajar yang akan dibangun melalui dua pendekatan yaitu intervensi dan habituasi. Kegiatan intervensi dikembangkan melalui suasana interaksi belajar-mengajar yang sengaja untuk dirancang demi pencapaian tujuan pembentukkan karakter yang peduli lingkungan dengan cara menerapkan kegiatan yang terstruktur. Agar proses pembelajaran tersebut berjalan dengan berhasil, peran guru PAK sebagai sosok panutan sangat menentukan. Sedangkan di dalam lingkungan kehidupan keluarga dan masyarakat, intervensi dilakukan dengan memberikan contoh pembelajaran melalui perilaku terpuji dan karakter yang baik. Sedangkan dalam konteks habituasi, di ciptakan suasana dan kondisi serta pemberian motivasi yang memungkinkan siswa di lingkungan sekolah, rumah, dan masyarakat, untuk membiasakan diri bertindak sesuai dengan nilai

12 Mariani Harmadi and Ruat Diana, "Tinjauan Psiko-Teologi Terhadap Fenomena Kekerasan Dalam Pacaran Pada Remaja," Evangelikal: Jurnal Teologi Injili dan Pembinaan Warga Jemaat 4, no. 1 (2020): 92-102. 
dan menjadi karakter yang telah diinternalisasi melalui proses intervensi. Proses pembudayaan dan pemberdayaan yang mencakup pemberian contoh, pembelajaran, pembiasaan, dan penguatan harus dikembangkan secara sistemik, holistik, dinamis, kuat serta berdasar argumentatif. ${ }^{13}$ Diharapkan, melalui pilar satuan pendidikan sekolah, keluarga dan masyarakat dapat dilakukan proses pembudayaan dan pemberdayaan nilai PAK berwawasan lingkungan hidup secara efektif.

Konsep eduecologi dalam PAK konteks sekolah dalam hal ini menyangkut bagaimana konsep PAK berwawasan lingkungan hidup itu di aplikasikan pendidik kepada murid. Konsep metode PAK berwawasan lingkungan hidup di sekolah dapat kita uraikan dari penjelasan-penjelasan dari umum ke khusus. Konsep eduecologi dalam PAK konteks sekolah dapat dilakukan melalui pengajaran pendidikan dan fasilitas yang bias dimanfaatkan. Melalui pendidikan, pengajaran dilakukan dalam konteks makro dan mikro. Di dalam konteks makro, kegiatan pendidikan berwawasan lingkungan hidup meliputi keseluruhan kegiatan planning, organizing, implementation dan pengendalian mutu, yang melibatkan seluruh unit utama di lingkungan pemangku kepentingan pendidikan nasional. Sedangkan dalam konteks mikro merupakan penyelenggaraan pendidikan dalam pembudayaan dan pemberdayaan pada tingkat sekolah. ${ }^{14}$ Konsep eduecologi dalam PAK konteks sekolah dapat dilakukan lewat pendekatan dalam konteks mikro dalam upaya mengaplikasikan nilai-nilai PAK berwawasan lingkungan hidup di sekolah.

Penyelenggaraan pendidikan pada konteks mikro berfokus kepada implementasi pendidikan PAK berwawasan lingkungan hidup di sekolah. Pendidikan menjadi dasar terdepan dalam upaya untuk membentuk karakter peduli lingkungan dan sekolah merupakan salah satu sektor utama yang paling optimal untuk memanfaatkan dan memperdayakan semua kondisi lingkungan belajar-mengajar yang ada untuk menguatkan, menginisiasi, memperbaiki, dan menyempurnakannya secara berkesinambungan tentang akan pentingnya PAK berwawasan lingkungan hidup. Adapun bentuk konsep implementasi PAK berwawasan lingkungan hidup di sekolah dapat kita pelajari melalui penyelenggaraan pendidikan dalam pemberdayaan dan pembudayaan secara mikro. Secara mikro konsep PAK berwawasan lingkungan hidup di sekolah dibagi dalam dalam beberapa pilar, yakni belajar mengajar di kelas; keseharian

${ }^{13}$ Endah Sulistyowati, Implementasi Kurikulum Pendidikan Karakter (Yogyakarta: Citra Aji Parama, 2012), 11-12.

${ }^{14}$ Ibid., 11-12. 
dalam bentuk pengembangan budaya sekolah seperti, ko-kurikuler dan ekstrakurikuler, serta keseharian di rumah dan masyarakat.

Konsep eduecologi PAK konteks sekolah yang dapat diimplementasikan dapat dilakukan dengan beberapa pendekatan, yaitu:

\section{Konsep PAK Berwawasan Lingkungan Hidup Melalui Kegiatan Belajar-} Mengajar

Konsep PAK berwawasan lingkungan hidup melalui kegiatan belajarmengajar ${ }^{15}$ yaitu dengan mengintegrasikannya ke dalam bahan ajar mata pelajaran PAK. Dalam hal ini guru Pak dapat mengintegrasikan ke dalam tematema pembelajaran PAK terkait penanaman nilai-nilai kristiani tentang menjaga dan memelihara lingkungan hidup. Hasil Lokakarya Strategi PAK di Indonesia tahun 1999 menyatakan bahwa hakikat PAK ialah usaha yang dilakukan secara terencana serta berkelanjutan dalam usaha untuk mengembangkan kemampuan peserta-didik supaya dengan pertolongan Roh Kudus dapat memahami dan menghayati kasih Allah di dalam Yesus Kristus yang dinyatakan dalam kehidupannya sehari-hari, baik terhadap sesama, orang lain dan lingkungan hidupnya. Untuk itu, setiap pengajar yang mengambil bagian dalam proses pembelajaran PAK memiliki keterpanggilan untuk mewujudkan tanda-tanda Kerajaan Allah dalam kehidupan pribadi maupun sebagai bagian dari komunitas. ${ }^{16}$

Menurut Peraturan Pemerintah Nomor 55 Tahun 2007 tentang pendidikan agama dan pendidikan keagamaan, disebutkan bahwa: pendidikan agama berfungsi membentuk manusia Indonesia yang beriman dan bertakwa kepada Tuhan Yang Maha Esa serta berakhlak mulia dan mampu menjaga kedamaian dan kerukunan hubungan inter dan antarumat beragama (Pasal 2 ayat 1). Selanjutnya disebutkan bahwa pendidikan agama bertujuan mengembangkan kemampuan peserta didik dalam memahami, menghayati, dan mengamalkan nilai-nilai agama yang menyerasikan penguasaannya dalam ilmu pengetahuan, teknologi dan seni (Pasal 2 ayat 2). ${ }^{17}$ Mata pelajaran PAK berfungsi untuk:

a) Memperkenalkan Allah dan karya-karya-Nya agar peserta didik bertumbuh iman percayanya dan meneladani Allah dalam hidupnya.

\footnotetext{
${ }^{15}$ Mahmud Alpusari, “Analisis Kurikulum Pendidikan Lingkungan Hidup Pada Sekolah Dasar Pekanbaru," Primary: Jurnal Pendidikan Guru Sekolah Dasar 2, no. 02 (2014): 10-17.

${ }^{16}$ Kementrian Pendidikan dan Kebudayaan, Pendidikan Agama Kristen dan Budi Pekerti (Jakarta: Kementerian Pendidikan dan kebudayaan, 2014), 9.

${ }^{17}$ Ibid., 10.
} 
b) Menanamkan pemahaman tentang Allah dan karya-Nya kepada peserta didik, sehingga mampu memahami, menghayati, dan mengamalkannya.

Mata pelajara PAK bertujuan;

a) Menghasilkan manusia yang dapat memahami kasih Allah di dalam Yesus Kristus dan mengasihi Allah dan sesama.

b) Menghasilkan manusia Indonesia yang mampu menghayati imannya secara bertanggung jawab serta berakhlak mulia dalam masyarakat majemuk. ${ }^{18}$

Penulis memahami bahwa apa yang diuraikan dari hakikat dan tujuan PAK adalah untuk menghayati dan memahami kasih Tuhan Yesus Kristus yang diaplikasikan didalam kehidupan keseharian, terhadap sesama dan alam. PAK berfokus untuk meningkatkan kemampuan murid-murid dalam menghayati, memahami dan menjalankan nilai-nilai keagamaan yang selaras dengan IPTEK. PAK berwawasan lingkungan hidup di sekolah disajikan dalam 2 aspek, yaitu aspek Allah sebagai sang pencipta, dan aspek tanggungjawab manusia terhadap alam yang juga memiliki kaitan dengan hakikat dan tujuan PAK. Secara komperhensif, peningkatan kompetensi inti dan kompetensi dasar PAK berwawasan lingkungan hidup pada pendidikan dasar dan menengah berpatokkan pada dogma tentang Allah sang pencipta dan karya-Nya. Pemahaman terhadap Allah sang pencipta dan karya-Nya akan terlihat dalam nilai-nilai kristiani yang diajarkan dalam kehidupan keseharian murid-murid. Manfaat pelajaran PAK berwawasan lingkungan hidup ialah supaya muridmurid mampu memahami, menghayati, serta mengamalkannya untuk memelihara dunia ciptaan Allah. Tujuan Pendidikan Agama Kristen Berwawasan Lingkungan Hidup adalah untuk Menghasilkan manusia yang dapat memahami Allah sebagai sang pencipta alam semesta dan memelihara alam ciptaan Allah sebagai tempat keberlangsungan hidup manusia. Menghasilkan manusia Indonesia yang mampu bertindak secara eko-teosentris terhadap alam secara berkelanjutan.

PAK telah terbentuk sejak umat Allah ada yang diawali dengan pemanggilan Abraham. Kemudian berkelanjutan didalam kehidupan $12 \mathrm{suku}$ Israel sampai pada zaman Perjanjian Baru. Sinagoge / rumah ibadah bangsa Yahudi bukan hanya dijadikan tempat ibadah, tetapi juga menjadi salah satu pusat kegiatan pengajaran-pendidikan bagi kaum anak-anak dan di tengahtengah keluarga orang Yahudi. ${ }^{19}$ Penulis memahami bahwa apa yang diuraikan dari landasan teologis, juga mengasumsikan bahwa PAK berwawasan

\footnotetext{
${ }^{18}$ Ibid., 10.

${ }^{19}$ Ibid., 11.
} 
lingkungan hidup harus di ajarkan secara berulang-ulang, dalam kaitannya dengan Allah sebagai Pencipta dan Allah selalu berada dalam dunia dalam hubungan dengan bumi. Hakikat Allah adalah pencipta, tanpa itu Dia bukanlah Allah. Oleh sebab itu, dunia ini berhubungan secara organisasi dengan Allah, bahkan Allah berada dalam dunia. Kesadaran itu harus melahirkan sikap tanggung jawab dari manusia bahwa ia hadir bersama ciptaan yang lain dan karenanya ia bertanggung jawab pula untuk menjaga, melindungi, merawat ciptaan yang lain sebagai bagian ciptaan Allah, inilah tanggung jawab manusia yang eko teosentris. Serta melakukan transformasi pendidikan agama Kristen berwawasan lingkungan hidup yang antroposentris menjadi eko-teosentris.

Dalam merekonstruksi pendidikan agama Kristen berwawasan lingkungan hidup yang dapat disebut pendidikan transformasi yang menjadi tujuan adalah perubahan paradigma berpikir dalam bertindak dan ber-relasi dengan alam, manusia di bawa kedalam terang pemerintahan Allah yang menginginkan keadilan sehingga siap berjuang secara bebas dan bertanggung jawab demi perbaikan hidup. Guru dan murid sebagai mitra untuk melakukan refleksi dan aksi bahkan keterlibatan warga gereja dalam melakukan dialog dan transformasi. Dengan demikian strategi pendidikan Kristen yang ekologis dan teosentris merupakan bagian dari pendekatan pendidikan Kristen transformatif yang secara keseluruhan melihat permasalahan ekologis sebagai tindakan dari memahami kitab suci dan kemudian di dialogkan dan di refleksikan dalam kurikulum mata pelajaran pendidikan agama Kristen.

PAK berwawasan lingkungan hidup merupakan salah satu proses pendidikan yang berupaya menumbuhkan kesadaran peserta didik yang pada akhirnya bersedia secara bertanggung jawab, melakukan perlindungan dan pelestarian lingkungan hidup. Tujuannya, supaya kualitas lingkungan dapat memberikan manfaat untuk kehidupan masyarakat dan keluarga, tidak saja pada generasi sekarang, akan tetapi berlangsung secara berkesinambungan kepada generasi berikutnya, serta tanggung jawab manusia dalam mengelola dunia ciptaan Allah. Dampak positifnya, peluang untuk meningkatkan potensi kesejahteraan masyarakat semakin luas, serta hadirnya kedamaian di bumi diantara semua mahluk hidup. ${ }^{20}$

Ada lima tujuan pendidikan lingkungan yang telah disepakati oleh dunia internasional, yaitu sebagai berikut. Pertama, dalam bidang pengetahuan: menolong setiap individu, untuk memperoleh berbagai pengalaman serta

\footnotetext{
${ }^{20}$ H. Abdul Karim, Manajemen Pendidikan Lingkungan Hidup Berbasis Partisipasi (Bandung: Kataba Group, 2018), 79.
} 
pengetahuan tentang apa yang di perlukan untuk mengelola, menciptakan dan menjaga lingkungan yang berkelanjutan. Kedua, dalam bidang kesadaran: menolong setiap individu untuk mendapatkan kesadaran dan kepekaan terhadap lingkungan secara komperhensif beserta isu-isu yang lingkungan hidup, pertanyaan, dan permasalahan yang berhubungan dengan lingkungan dan pembangunan. Ketiga, dalam bidang perilaku: menolong setiap individu untuk memperoleh paduan norma dan nilai perasaan peduli terhadap lingkungan dan motivasi untuk berpartisipasi aktif dalam perbaikan dan perlindungan lingkungan. Keempat, dalam bidang ketrampilan: membantu setiap individu, untuk mendapatkan ketrampilan untuk mengantisipasi, mengidentifikasi, dan mencegah kerusakan lingkungan. Kelima, dalam bidang partisipasi: memberikan ruang dan kesempatan dan motivasi terhadap setiap individu untuk terlibat secara aktif dalam menciptakan lingkungan yang berkelanjutan. ${ }^{21}$ Oleh sebab itu PAK berwawasan lingkungan hidup diperlukan sebagai upaya bagaimana setiap individu dapat mengelola secara bijaksana sumber daya alam yang telah di anugerahkan Allah kepada kita.

Ada beberapa landasan teologis konsep eduecologi PAK konteks sekolah sebagai dasar pendekatan relasi manusia terhadap alam yang dapat di ajarkan oleh guru PAK yaitu: (1) model imago dei, (2) model organis, (3) panenteisme, (4) teologi kenosis, dan (5) teologi Roh Kudus. Kelima model ini digunakan untuk menganalisis pergerakan pemikiran manusia terhadap alam. ${ }^{22}$ Model yang pertama, seorang penganut paham eko-teologi yang bernama John Stott, berpendapat bahwa posisi manusia yang diciptakan menurut gambar-rupa Allah atau imago dei ialah sikap dasar manusia untuk melindungi dunia ciptaan Allah. Diciptakan menurut gambar-rupa Allah memiliki tiga makna yaitu hubungan, komunitas, dan tugas khusus. Pertama, manusia yang diciptakan menurut gambar-rupa Allah harus memiliki hubungan yang baik dengan Allah yang menunjukkan sikap menghadirkan damai pada semua ciptaan Allah. Kedua, Allah melihat dari awal penciptaan melihat seluruh ciptaan-Nya sebagai sebuah komunitas yang saling menopang. Manusia diciptakan untuk menopang ciptaan yang lainnya sebagaimana ciptaan yang lainnya menopang keberlangsungan hidup manusia. Ketiga, manusia sebagai gambar-rupa Allah diberikan

${ }^{21}$ Sri Mantini Rahayu Sedyawati, Dewi Liesnoor Setyowati, Sunarko, Rudatin, ed., Pendidikan Lingkungan Hidup (Semarang: Universitas Negeri Semarang, 2014), 5.

22 Irene Ludji, "Respon Agama Kristen Terhadap Kerusakan Lingkungan Hidup" (Disampaikan Dalam Seminar Studium Generale di Universitas Kristen Satya Wacana), 2014. h. 69-70. 
kekuasaan untuk "menaklukkan" (Ibrani: Kabbas) dan "berkuasa" (Ibrani: Raddah) yang ditafsirkan oleh Stott sebagai tanggung-jawab untuk "mengolah/mengusahakan, menjaga/memelihara dunia ciptaan Allah. Model imago dei yang dikembangkan oleh Stott ingin menegaskan bahwa manusia adalah ciptaan Allah yang lebih istimewa dibandingkan dengan ciptaan yang lain, sehingga menitiberatkan tanggung-jawab kepada manusia untuk memelihara yang lainnya. ${ }^{23}$

Model yang kedua adalah model organis. Model "organis" adalah paham yang dikembangkan oleh John Macquarrie. Ajaran ini tidak menerima pemisahan antara sang pencipta dengan yang diciptakan-Nya sebagaimana yang dikemukakan oleh White dan Cox. Macquarrie menjelaskan bahwa ada banyak bagian Alkitab, selain Kejadian 1 dan 2, yang menegaskan hubungan yang tidak terpisah antara Allah sebagai Pencipta dengan dunia dan isinya sebagai ciptaan (misalnya Kej. 9:10, Mzm. 19: 1; 29). Didalam model "organis", Allah tidak dilihat sebagai Allah yang di atas manusia tetapi sebaliknya Allah dilihat sebagai pemberi kehidupan kepada ciptaannya. Kata "organis" menghunjuk pada ciri khas organisme yang saling berketergantungan, membutuhkan, dan menopang satu dengan yang lain. Sebagaimana organisme, demikian pula hubungan antara Allah dengan ciptaan-Nya yaitu hubungan kebergantungan yang saling memberikan makna. ${ }^{24}$

Model ke tiga dikemukakan Jay B McDaniel, dengan menggunakan model panenteisme. Pengertian panenteisme berbeda dengan makna panteisme. Panteisme mempercayai bahwa sang Ilahi ada dalam semua ciptaan-nya, sedangkan panenteisme mempercayai bahwa seluruh ciptaan adalah bagian dari karya Allah. Ajaran panteisme melihat bahwa sang Ilahi tidak terbedakan dari ciptaan-nya, sedangkan didalam ajaran penenteisme Allah berbeda dengan ciptaan-nya, namun tetap memiliki hubungan dekat dengan ciptaan-nya. Ajaran panenteisme melihat bahwa seluruh ciptaan harus ber-relasi secara harmonis dengan sang pencipta-Nya. ${ }^{25}$

${ }^{23}$ Haskarlianus Pasang, Mengasihi Lingkungan: Bagaimana Orang Kristen, Keluarga dan Gereja Mempraktikkan Kebenaran Firman Tuhan Untuk Menjadi Jawaban Atas Krisis Ekologi dan Perubahan Iklim di Bumi Indonesia (Jakarta: Literatur Perkantas, 2011), 96-98.

${ }^{24}$ M. Harun, Taklukkanlah Bumi dan Berkuasalah: Alkitab Ibrani dan Dampaknya Untuk Lingkungan Hidup (Jakarta: STF Driyarkara, 1998), 31.

${ }^{25}$ Ibid., 33-34 
Sallie McFague, adalah teolog perempuan yang berbicara mengenai pentingnya teologi "kenosis". 26 Teologi kenosis ialah teologi yang memfokuskan pada ajaran inkarnasi Tuhan Yesus Kristus ke dalam dunia ini. Ajaran yang dikembangkan oleh McFague ini tidak melihat Allah terpisah dari ciptaan-Nya. Sebab Allah sudah berinkarnasi serta telah menjadi bahagian dari dunia didalam diri Yesus Kristus, Allah menyatu dengan dunia. Oleh karena itu, Allah dan dunia adalah kesatuan. Sebagai konsekuensinya dunia ini bagian dari kepunyaan Allah. Akan tetapi Allah tidak bisa dibatasi hanya dalam dunia saja tetapi Allah dapat diidentifikasi lewat ciptaan-Nya. ${ }^{27}$

Tawaran yang terakhir ialah paham eko-teologi yang ditawarkan oleh Denis Edwards yang menekankan peran dari "Roh Kudus" didalam dunia. Edwards, melihat peristiwa penciptaan sebagai proses terus menerus berlangsung dengan pengawalan dari Roh Allah sendiri. Roh Kudus berperan untuk menyertai ciptaan serta merangkul ciptaan itu menuju sebuah kebersinambungan di dunia ini. Roh Kudus turut menderita dalam ciptaan-nya yang menderita serta memberikan pemulihan kepada ciptaan. Menurut Edwards, Roh Kudus berperan penting karena "di dalam roh, segala makhluk adalah bagian dari kita, dan kita bagian dari mereka, bersama-sama dihidupkan oleh satu Roh yang merangkum semua”. Roh Kudus menjadi sumber penyatu antara ciptaan dengan pencipta-Nya dalam konteks yang saling memelihara. ${ }^{28}$

Kelima model tawaran pendekatan manusia terhadap alam yang dipaparkan diatas memiliki dua ciri yang relatif sama yaitu, pertama, manusia bukan pusat dari ciptaan. Manusia bukanlah satu-satunya ciptaan yang penting bagi Allah. Ajaran Alkitab menyatakan bahwa manusia adalah ciptaan Allah sebagaimana dengan ciptaan yang lainnya. Sebaliknya manusia yang setara kedudukannya dengan ciptaan Allah yang lain, diingatkan untuk menjalankan peran memuliakan Allah lewat hidup yang harmonis dengan ciptaan lain, sebagai satu keutuhan ciptaan. Manusia adalah pemelihara ciptaan Allah yang bertanggungjawab kepada Allah untuk menjaganya. Kedua, keutuhan antara Pencipta dan ciptaan. Baik dengan menelusuri ayat-ayat Alkitab selain Kejadian 1 dan 2, menafsir ulang kisah inkarnasi Yesus Kristus ke dalam dunia, maupun

26 Robert P. Borrong, "Kronik Ekoteologi: Berteologi Dalam Konteks Krisis Lingkungan,” Stulos 17, no. 2 (2019): 185-212.

${ }^{27}$ Ludji, "Respon Agama Kristen Terhadap Kerusakan Lingkungan Hidup ('Disampaikan Dalam Seminar Studium Generale Di Universitas Kristen Satya Wacana' Pada Tanggal 1 Maret 2014)."

${ }^{28}$ M. Harun, Taklukkanlah Bumi dan Berkuasalah: Alkitab Ibrani dan Dampaknya Untuk Lingkungan Hidup. 
dengan mengutamakan peran Roh Kudus, model-model di atas meyakini bahwa Allah sebagai Pencipta tidak terpisah dari ciptaanNya. Allah hadir di tengahtengah ciptaanNya lewat inkarnasi Yesus dan menyatu dengan ciptaanNya. Allah menuntun ciptaanNya lewat Roh Kudus dan bergumul bersama dengan mereka. Allah menderita bersama ciptaanNya dan menguatkan seluruh ciptaanNya untuk menuju kepada pemulihan. Di antara kelima model ekoteologi di atas sudah seharusnya bersifat eko-teosentris dalam memelihara alam. Sebagai penyandang citra Allah, manusia diberikan tugas untuk melaksanakan kekuasaan Allah di bumi, melalui pengelolaan dan pemeliharaan alam secara baik dan berkelanjutan. ${ }^{29}$

PAK berwawasan lingkungan hidup sangat penting dalam menanamkan keyakinan dan pemahaman peserta didik dalam memelihara alam secara ekoteosentris lewat kegiatan belajar-mengajar. Melalui wahana pembelajaran PAK berwawasan lingkungan hidup, peserta didik dapat merubah cara pandang, meningkatkan kapasitas wawasan eko-teosentrisnya sehingga dapat menggerakkan perilaku dan gaya hidup yang bersahabat dengan alam dan mahluk hidup lainnya. Ajaran kristen telah memberikan pedoman dan seperangkat norma dan nilai untuk mengelola, menjaga, dan melestarikan dunia ciptaan Allah. Nilai-nilai eko-teosentris dalam ajaran kristen inilah yang perlu ditransformasikan kepada peserta didik agar memiliki pengetahuan atau pemahaman, keterampilan serta perilaku yang sesuai dengan nilai dan norma ajaran kristen dalam konteks relasinya dengan alam. Melalui jalur pendidikan, proses internalisasi dan transformasi nilai ekologis akan terjamin sasarannya serta dapat dilaksanakan secara sistematik dan berkesinambungan.

Konsep PAK Berwawasan Lingkungan Hidup Lewat Budaya Sekolah (Melalui Kegiatan Sehari-Hari Di Sekolah)

Konsep PAK berwawasan lingkungan hidup lewat budaya sekolah (melalui kegiatan sehari-hari di sekolah) ${ }^{30}$ yang dapat di manfaatkan oleh guru PAK untuk menanamkan nilai-nilai pemeliharaan lingkungan sekolah yang telah di anugerahkan Allah. PAK berwawasan lingkungan hidup dapat dilakukan melalui kegiatan rutin, keteladanan guru PAK, kegiatan spontan, serta

${ }^{29}$ Silva S Thesalonika Ngahu, "Mendamaikan Manusia Dengan Alam: Kajian Ekoteologi Kejadian 1: 26-28," Pengarah: Jurnal Teologi Kristen 2, no. 2 (2020): 77-88.

${ }^{30}$ Ahmad Fajarisma Budi Adam, "Analisis Implementasi Kebijakan Kurikulum Berbasis Lingkungan Hidup Pada Program Adiwiyata Mandiri Di SDN Dinoyo 2 Malang," Jurnal Kebijakan dan Pengembangan Pendidikan 2, no. 2 (2014): 166-173. 
pengkondisian lingkungan. Kegiatan rutin. Kegiatan rutin dalam rangka mendidik anak-anak peduli lingkungan hidup pada diri siswa dilakukan melalui kegiatan rutin harian, mingguan dan isidentil/sewaktu-waktu. ${ }^{31}$ Kegiatan rutin harian yang dilaksanakan di sekolah yang dapat dimanfaatkan oleh guru PAK adalah piket harian oleh siswa, tugas wajib piket harian terbagi menjadi dua, yakni menjaga dan membersihkan lingkungan kelas serta menjaga dan merawat taman yang berada di depan kelasnya masing-masing. Kegiatan rutin mingguan adalah sabtu bersih, kegiatan sabtu bersih dilaksanakan setiap sabtu genap tiap bulannya dalam artian sabtu kedua dan keempat tiap bulannya. Kegiatan hari sabtu bersih ini dilaksanakan dalam rangka bersih-bersih ruangan kelas, lingkungan sekolah, serta berkebun secara bersama-sama. Kegiatan rutin yang bersifat isidentil, kegiatan rutin yang bersifat isidentil atau sewaktu-waktu ialah peringatan hari-hari lingkungan hidup yang waktu pelaksanaannya menyesuaikan dengan tanggal peringatan hari lingkungan hidup tersebut sebagai contoh: Hari Lingkungan Hidup Sedunia (HLHS) 5 Juli; Hari Bumi 22 April; Hari Peduli Sampah Nasional 21 Februari; Hari Air Sedunia 22 Maret dan sebagainya. Serta membuat kegiatan-kegiatan perlombaan yaitu, lomba kebersihan kelas, pemberian penghargaan pada siswa yang peduli akan lingkungan hidup, siswa yang rajin, siswa teladan dll.

Keteladanan langsung dari guru PAK. ${ }^{32}$ Keteladanan dari guru PAK menjadi suatu strategi yang digunakan dalam menanamkan pendidikan peduli lingkungan hidup di sekolah, seperti terlibat secara langsung bersama-sama siswa untuk memungut sampah dan membuangnya pada tempatnya, memberi contoh membuang sampah pada tempatnya (organik, anorganik, dll.), menanam pohon, merawat taman sekolah dan menyediakan tong sampah serta tindakan dan prilaku yang mengarah kepada menjaga, merawat kebersihan dan keasrian lingkungan sekolah. ${ }^{33}$ Dalam menanamkan budaya peduli lingkungan hidup di sekolah dengan membuat peraturan atau disiplin yang dibuat dan disepakati bersama antara para murid dan guru dalam satu kelas. Misalkan barang siapa yang membuang sampah sembarangan, tidak mengerjakan tugas piketnya, tidak merawat tamannya akan dikenakan denda Rp. 5.000,- dan dana ini nantinya

${ }^{31}$ Fauzy Setyobudi and Saliman Marsudi, "Pendidikan Lingkungan Hidup Di Smp Negeri 3 Kebumen Jawa Tengah,” Jipsindo 5, no. 1 (2018): 1.

32 Sujiyo Miranto, "Integrasi Konsep-Konsep Pendidikan Lingkungan Hidup dalam Pembelajaran di Sekolah," Edusains 9, no. 1 (2017): 81-88.

${ }^{33}$ Mirza Desfandi, "Mewujudkan Masyarakat Berkarakter Peduli Lingkungan Melalui Program Adiwiyata," SOSIO DIDAKTIKA: Social Science Education Journal 2, no. 1 (2015): 31-37. 
digunakan untuk kebersihan lingkungan hidup, atau dengan cara di beri hukuman dengan piket selama 2-3 hari.

Kegiatan spontan. Dalam menanamkan pendidikan peduli lingkungan hidup, terdapat sebuah kegiatan spontan yang dilakukan oleh guru PAK. Kegiatan spontan tersebut dapat dilakukan dengan bentuk ajakan dan memotivasi siswa untuk selalu menjaga kebersihan lingkungan dan dapat pula bersifat peringatan atau teguran ketika terdapat perilaku siswa yang belum mencerminkan kepedulian terhadap lingkungan, memberikan penghargaan dan pujian kepada siswa-siswa yang peduli terhadap kebersihan lingkungan di sekolah atau lewat ceramah setiap hari senin ketika melaksanakan upacara, khotbah, ibadah sekolah, dan lain sebagainya.

Pengkondisian lingkungan. Perancangan situasi yang sengaja dibuat dalam rangka untuk membentuk karakter siswa yang peduli lingkungan hidup di sekolah yang meliputi, pengadaan sarana-prasarana yang terdiri dari penyediaan tempat bak sampah yang terpilah menjadi 3 jenis tempat sampah (plastik, daun, dan kertas), tersedianya alat kebersihan skala kelas, spanduk dan majalah dinding, dengan muatan ajakan cinta lingkungan, penyediaan bunga dan tanaman pohon ramah lingkungan.

Melalui wahana eduecologi PAK konteks sekolah (melalui kegiatan sehari-hari di sekolah), peserta didik dapat merubah cara pandang, meningkatkan kapasitas wawasan eko-teosentrisnya sehingga dapat menggerakkan perilaku dan gaya hidup yang bersahabat dengan alam dan mahluk hidup lainnya untuk mengelola, menjaga, dan melestarikan dunia ciptaan Allah

Konsep PAK Berwawasan Lingkungan Hidup Lewat Kegiatan Ekstrakurikuler Di Sekolah

Konsep PAK berwawasan lingkungan hidup lewat kegiatan ekstrakurikuler di sekolah. ${ }^{34}$ Sekolah atau guru PAK harus menggunakan dan memanfaatkan kegiatan ekstrakurikuler yang dekat dengan lingkungan sebagai strategi mendidikan anak untuk cinta dan peduli lingkungan, dengan kegiatan mengumpulkan sampah dan membuang pada tempatnya, mengolah sampah organik menjadi pupuk kompos dan sampah anorganik di jadikan bahan kreativitas (bunga plastik, tempat pensil, tas dll.) yang dilakukan di luar jam

\footnotetext{
${ }^{34}$ Shanta Rezkita and Kristi Wardani, "Pengintegrasian Pendidikan Lingkungan Hidup Membentuk Karakter Peduli Lingkungan Di Sekolah Dasar," TRIHAYU: Jurnal Pendidikan KeSD-an 4, no. 2 (2018): 327-331.
} 
pelajaran formal, melakukan penanaman pohon, berkebun, menanam bunga, eko-kem dll. ${ }^{35}$ Kegiatan pramuka dan Outbond / atau kegiatan OSIS di sekolah menjadi kegiatan ekstrakurikuler yang dipilih untuk membentuk karakter peduli lingkungan secara eko-teosentris.

Konsep PAK berwawasan lingkungan hidup lewat kegiatan ekstrakurikuler di sekolah di sampaikan sebagai dasar pentingnya pengajaran pendidikan lingkungan hidup bagai anak-anak berkaitan dengan petingnya lingkungan hidup bagi manusia. Lingkungan hidup adalah semua jumlah benda yang hidup dan tidak hidup serta keadaan yang terdapat dalam ruangan yang kita tempati. Manusia di sekitar kita merupakan bagian dari lingkungan hidup kita masing-masing. ${ }^{36}$ Manusia hidup di bumi tidaklah seorang diri, melainkan bersama makhluk yang lainnya, yaitu, tumbuhan, hewan, dan lain sebagainya. Makhluk hidup yang lainnya bukan sekedar teman hidup yang hidup bersama secara pasif dengan manusia, melainkan kehidupan manusia itu terkait secara erat dengan mahluk lainnya. Sebab manusia tidak akan dapat bertahan hidup tanpa alam. Fakta membuktikan, dengan mengandaikan di bumi ini tidak ada mahluk lainnya selain manusia, darimanakah manusia dapat memenuhi kebutuhan kehidupannya. Sebaliknya apabila tidak ada manusia, hewan, tumbuhan dan mahluk hidup lainnya pasti dapat bertahan hidup, seperti yang terlihat dari sejarah bumi sebelum adanya manusia. ${ }^{37}$ Oleh sebab itu pandangan yang mengatakan bahwa manusia ialah manusia yang paling berkuasa adalah tidak benar. Seharusnya manusia menyadari bahwa dirinya lah yang membutuhkan makhluk hidup lainnya untuk keberlangsungan hidupnya dan bukannya alam yang membutuhkan manusia untuk kelangsungannya.

Manusia dan lingkungan hidupnya memiliki hubungan saling berketergantungan. Hubungan manusia dengan lingkungan hidup-nya bersifat holistik, sebab pada umumnya dalam lingkungan hidup itu terdapat banyak mahluk hidup. Dari lingkungan hidupnya, manusia memanfaatkan bagianbagian dari unsur lingkungannya seperti udara segar untuk pernafasan, air untuk kebutuhan sehari-hari, hewan dan tumbuhan untuk makanan, serta tanah/lahan untuk tempat tinggal dan produksi pertanian. ${ }^{38}$ Relasi manusia dengan

${ }^{35}$ Sholihah and Nadzifah, "Aplikasi Pendidikan Lingkungan Hidup Bagi Anak Tingkat Sekolah Dasar Dalam Membentuk Kepedulian Anak Terhadap Lingkungan."

${ }^{36}$ A. Tresna Sastrawijaya, Pencemaran Lingkungan (Jakarta: Rineka Cipta, 2009), 7

${ }^{37}$ Otto Soemarwoto, Ekologi, Lingkungan Hidup dan Pembangunan (Jakarta: Djambatan, 2008), 51.

${ }^{38}$ Otto Soemarwoto, Ekologi, Lingkungan Hidup dan Pembangunan (Jakarta: Djambatan, 2008), 53-55. 
lingkungan hidup-nya ialah hubungan timbal-balik. Manusia berada di dalam lingkungan hidup-nya dan tidak dapat terpisahkan daripadanya. Oleh sebab itu prilaku manusia, kondisi alam dan kondisi sosial, merupakan bagian dari unsur fungsi lingkungan hidup kita. ${ }^{39}$ Eksistensinya terjadi sebagian karena sifat-sifat keturunannya dan sebagian lagi karena lingkungan hidupnya. Interaksi antara manusia dan lingkungan hidupnya akan memberikan ciri khasnya masingmasing. Demikian pula lingkungan hidup terbentuk oleh adanya interaksi antara lingkungan hidup dengan manusia. ${ }^{40}$

Hubungan manusia dengan lingkungan hidup-nya terdapat hubungan yang dinamis. Perubahan yang terjadi didalam suatu lingkungan hidup akan berdampak penyesuaian diri dengan keadaan yang baru. Perubahan prilaku manusia ini akan menyebabkan pula perubahan prilaku dalam lingkungan hidup. ${ }^{41}$ Dengan adanya hubungan yang dinamis antara manusia dengan lingkungan hidupnya itu, dapatlah dikatakan bahwa "hanya didalam lingkungan hidup yang baik, manusia dapat bertahan hidup dari generasi ke generasi, dan hanya dengan manusia yang baik lingkungan hidup dapat berkembang kearah yang optimal". Jadi, sangat jelas bahwa lingkungan hidup yang baik sangat berfungsi dan berhubungan erat dengan manusia.

Menurut hemat penulis, lingkungan hidup itu berguna bagi manusia sebagai tempat untuk bertahan hidup dan penyokong keberlangsungan hidupnya dan manusia merupakan salah satu komponen penting dalam lingkungan hidup. Antara manusia dan lingkungannya memiliki hubungan timbal balik. Hal ini berhubungan dengan perilaku manusia dalam interaksinya dengan lingkungannya yang dibuktikan dengan aktivitas manusia dalam mengelola dan mengambil sumber daya alam. Jelaslah bahwa manusia adalah bagian integral lingkungan hidupnya. Manusia tanpa alam, manusia tidak dapat melangsungkan hidupnya, tetapi alam tanpa manusia, alam dapat melangsungkan hidupnya sebagaimana dia adanya sejak awal. ${ }^{42}$

Manfaat pengajaran PAK berwawasan lingkungan hidup lewat kegiatan ekstrakurikuler di sekolah merupakan contoh kongkrit eko-teologi yang dapat di aplikasikan oleh guru PAK terhadap siswa dan siswa dapat langsung mempraktekkannya secara kongkrit bagaimana memelihara dan mengelola alam ciptaan Tuhan dengan baik. Dengan kegiatan ini siswa akan semakin menyadari

\footnotetext{
${ }^{39}$ R. Holdridge, Life Zone Ecology (Costan Rica: Tropical Science Center, 1967), 6.

${ }^{40}$ A. Tresna Sastrawijaya, Pencemaran Lingkungan (Jakarta: Rineka Cipta, 2009), 7.

${ }^{41}$ William Chang, Moral Lingkungan Hidup (Yogyakarta: Kanisius, 2011), 29-30.

${ }^{42}$ Ledy Manusama, “Allah dan Alam,” Kenosis 1, no. 2 (2015): 187-203.
} 
betapa pentingnya untuk menjaga dan memelihara lingkungan hidupnya dengan baik agar ia dapat bertahan hidup dan memelihara dunia ciptaan Allah.

Konsep PAK Berwawasan Lingkungan Hidup Lewat Peran Serta Orang Tua Dari Siswa

Penguatan pendidikan dari keluarga juga selalu diupayakan lewat orangtua siswa. Pertemuan ketika pembagian raport dan momen pertemuan lain yang dilakukan dengan orang tua siswa menjadi waktu yang digunakan sekolah dalam berupaya merangkul para orang tua siswa agar satu visi dan misi dalam mendidik para siswa, khususnya terkait dengan pembentukkan kepribadian siswa peduli juga akan lingkungan hidup di rumah. Serta berupaya memberikan pemahaman tentang bagaimana menanamkan karakter peduli lingkungan kepada para orang tua siswa melalui kegiatan-kegiatan penyuluhan yang dilakukan oleh komite sekolah, jadi tidak hanya memberikan pemahaman kepada siswa akan pentingnya menjaga lingkungan hidup, akan tetapi orang tua siswa pun diberi pemahaman yang sama. Sehingga pengajaran PAK berwawasan lingkungan di sekolah bersinergi dengan pengajaran orang tua di rumah terhadap anakanaknya.

\section{Konsep PAK Berwawasan Lingkungan Hidup Lewat Peran Serta Gereja}

Pengajaran dan penanaman perilaku peduli lingkungan hidup sebagai karya ciptaan Allah diajarkan di gereja lewat perenungan khotbah di sekolah minggu, remaja dan umum yang dilakukan oleh Pendeta maupun guru PAK. Menanamkan nilai "peduli lingkungan hidup sebagai ciptaan Allah adalah bagian dari Iman", dan Iman tanpa perbuatan adalah mati (Yak. 2:18, 26). Kerusakan alam yang sedang terjadi saat ini adalah juga persoalan moral, krisis moral secara global, sebab sebagian besar berasal dari tindakan perilaku manusia. Oleh karena itu, perlu etika dan moralitas untuk mengatasinya, yaitu etika tanggung jawab (Kej. 1:26-28 dan 2:15). Merubah paradigma manusia yang antroposentris menjadi eko-teosentris. Serta mengajarkannya secara berkesinambungan kepada anak-anak (Ul. 6:7).

\section{Implementasi}

Berdasarkan uraian di atas tentang konsep eduecologi dalam PAK konteks sekolah tidak serta-merta diajarkan secara sekuler, namun dalam setiap kegiatan-kegiatan di atas guru PAK dapat menanamkan nilai-nilai kekristenan kepada siswa tentang betapa pentingnya menjaga dan memelihara alam sebagai 
bagian ciptaan Allah dan tempat berlangsungnya kehidupan manusia di bumi. Namun metodologi ini berpeluang besar untuk mengajarkan PAK berwawasan lingkungan hidup secara eko-teosentris dan siswa dapat langsung memaknai lingkungan hidup sebagai karya ciptaan Allah yang harus dikelola/diusahakan, menjaga/merawat lingkungan hidup yang telah di ciptakan Allah (Kej. 1:26-28). Oleh karena itu, PAK berwawasan lingkungan hidup menuntut tanggung jawab moral intrinsik dan spesifik dari setiap siswa di sekolah demi terciptanya suatu jalinan relasi jejaringan yang harmonis antara manusia terhadap alam dan seluruh makhluk ciptaan dengan Allah (bd. Mzm. 104:10-18). Konsep PAK berwawasan lingkungan hidup dalam konteks sekolah akan membawa peserta didik kepada pengenalan nilai PAK berwawasan lingkungan hidup secara kognitif dimana PAK berwawasan lingkungan hidup mempunyai fungsi untuk meningkatkan pemahaman terhadap permasalahan lingkungan secara ekoteosentris. Secara afektif, PAK berwawasan lingkungan hidup berfungsi meningkatkan penerimaan, penilaian, mengimani dalam menata kehidupan dalam keselarasan mengenai relasi di antara semua kehidupan alam semesta, yaitu antara manusia dengan manusia yang mempunyai dampak terhadap alam dan antara manusia dan makhluk hidup lainnya atau dengan alam secara menyeluruh dan berpusat kepada Allah. Secara psikomotorik, PAK berwawasan lingkungan hidup berperan meniru, memanipulasi dalam upaya meningkatkan budaya mencintai lingkungan sebagai karya ciptaan Allah.

\section{Simpulan}

Konsep eduecologi dalam PAK konteks sekolah dalam perspektif Kristen sangatlah penting untuk diterapkan dimasa kini agar problematika lingkungan tidak semakin akut dan peranan PAK berwawasan lingkungan hidup memberikan penekanan pada pemeliharaan lingkungan hidup secara ekoteosentris. Dalam hal ini, secara khusus guru PAK perlu memikirkan kembali teologi ekologi yang menggunakan pendekatan Eko-Teosentris holistik dalam upaya pemulihan relasi manusia terhadap alam. PAK berwawasan lingkungan hidup yang di ajarkan sejak dini menjadi solusi utama yang harus dilakukan agar generasi muda memiliki bekal pemahaman tentang lingkungan hidup secara Eko-Teosentris yang kokoh. Pendidikan agama Kristen berwawasan lingkungan hidup diharapkan mampu menjembatani dan mendidik manusia berperilaku bijaksana dalam ber-relasi dengan alam. Konsep PAK berwawasan lingkungan hidup dapat dilakukan melalui pengajaran pendidikan dan fasilitas yang bias dimanfaatkan. Melalui pendidikan, pengajaran dilakukan dalam konteks makro 
dan mikro. Konsep metodologi PAK berwawasan lingkungan hidup yang dapat diimplementasikan di sekolah dapat dilakukan dengan beberapa pendekatan yaitu, PAK berwawasan lingkungan hidup melalui kegiatan belajar-mengajar; lewat budaya sekolah (melalui kegiatan sehari-hari di sekolah); melalui kegiatan rutin di sekolah, keteladanan guru PAK, kegiatan spontan, serta pengkondisian lingkungan; lewat peran serta orang tua dari siswa serta lewat peran serta gereja.

\section{Daftar Pustaka}

A. Tresna Sastrawijaya. Pencemaran Lingkungan. Jakarta: Rineka Cipta, 2009. Adam, Ahmad Fajarisma Budi. "Analisis Implementasi Kebijakan Kurikulum Berbasis Lingkungan Hidup Pada Program Adiwiyata Mandiri Di SDN Dinoyo 2 Malang." Jurnal Kebijakan dan Pengembangan Pendidikan 2, no. 2 (2014): 166-173.

Alpusari, Mahmud. "Analisis Kurikulum Pendidikan Lingkungan Hidup Pada

Sekolah Dasar Pekanbaru." Primary: Jurnal Pendidikan Guru Sekolah Dasar 2, no. 02 (2014): 10.

Borrong, Robert P. "Kronik Ekoteologi: Berteologi Dalam Konteks Krisis Lingkungan." Stulos 17, no. 2 (2019): 185-212.

Chang, William. Moral Lingkungan Hidup. Yogyakarta: Kanisius, 2011.

Desfandi, Mirza. "Mewujudkan Masyarakat Berkarakter Peduli Lingkungan Melalui Program Adiwiyata." SOSIO DIDAKTIKA: Social Science Education Journal 2, no. 1 (2015): 31-37.

Dewi Liesnoor Setyowati, Sunarko, Rudatin, Sri Mantini Rahayu Sedyawati, ed.

Pendidikan Lingkungan Hidup. Semarang: Universitas Negeri Semarang, 2014.

Harmadi, Mariani, and Ruat Diana. "Tinjauan Psiko-Teologi Terhadap Fenomena Kekerasan Dalam Pacaran Pada Remaja." Evangelikal: Jurnal Teologi Injili dan Pembinaan Warga Jemaat 4, no. 1 (2020): 92-102.

Harun, M. Taklukkanlah Bumi Dan Berkuasalah: Alkitab Ibrani Dan Dampaknya Untuk Lingkungan Hidup. Jakarta: STF Driyarkara, 1998.

Haskarlianus Pasang. Mengasihi Lingkungan: Bagaimana Orang Kristen, Keluarga Dan Gereja Mempraktikkan Kebenaran Firman Tuhan Untuk Menjadi Jawaban Atas Krisis Ekologi Dan Perubahan Iklim Di Bumi Indonesia. Jakarta: Literatur Perkantas, 2011.

Holdridge, R. Life Zone Ecology. Costan Rica: Tropical Science Center, 1967.

Karim, H. Abdul. Manajemen Pendidikan Lingkungan Hidup Berbasis Partisipasi. Bandung: Kataba Group, 2018.

Kebudayaan, Kementrian Pendidikan dan. Pendidikan Agama Kristen Dan Budi Pekerti. Jakarta: Kementerian Pendidikan dan kebudayaan, 2014.

Krismawati, Nanik Supriyanai, and Chryssanti Widya. Statistika Lingkungan Hidup Indonesia 2020. Jakarta: Badan Pusat Statistika, 2020. 
Ledy Manusama. “Allah Dan Alam.” Kenosis 1, no. 2 (2015): 187-203.

Ludji, Irene. "Respon Agama Kristen Terhadap Kerusakan Lingkungan Hidup ('Disampaikan Dalam Seminar Studium Generale Di Universitas Kristen Satya Wacana' Pada Tanggal 1 Maret 2014),” 2014.

Maghfur, M. "Pendidikan Lingkungan Hidup Dan Masa Depan Ekologi Manusia." Edukasia Islamika 8, no. 1 (2010): 57-71.

Miranto, Sujiyo. "Integrasi Konsep-Konsep Pendidikan Lingkungan Hidup Dalam Pembelajaran Di Sekolah.” Edusains 9, no. 1 (2017): 81-88.

Mulyana, Rachmat. "Penanaman Etika Lingkungan Melalui Sekolah Perduli Dan Berbudaya Lingkungan." Jurnal Tabularasa PPS Unimed 6, no. 2 (2009): 175-180.

Ngahu, Silva S Thesalonika. "Mendamaikan Manusia Dengan Alam: Kajian Ekoteologi Kejadian1 : 26-28." Pengarah: Jurnal Teologi Kristen 2, no. 2 (2020): 77-88.

Panjaitan, Firman. "MembangunTeologi Pertanian Melalui Pembacaan Lintas Tekstual Injil Matius Dan Kosmologi Jawa." Bonafide: Jurnal Teologi dan Pendidikan Kristen 1, no. 1 (2020): 44-64.

Rezkita, Shanta, and Kristi Wardani. "Pengintegrasian Pendidikan Lingkungan Hidup Membentuk Karakter Peduli Lingkungan Di Sekolah Dasar." TRIHAYU: Jurnal Pendidikan Ke-SD-an 4, no. 2 (2018): 327-331.

Setyobudi, Fauzy, and Saliman Marsudi. "Pendidikan Lingkungan Hidup Di Smp Negeri 3 Kebumen Jawa Tengah.” Jipsindo 5, no. 1 (2018): 1.

Sholihah, Hidayatus, and Lum'atun Nadzifah. "Aplikasi Pendidikan Lingkungan Hidup Bagi Anak Tingkat Sekolah Dasar Dalam Membentuk Kepedulian Anak Terhadap Lingkungan." Islamic Review: Jurnal Riset dan Kajian Keislaman 7, no. 2 (2018): 174-190.

Soemarwoto, Otto. Ekologi, Lingkungan Hidup Dan Pembangunan. Jakarta: Djambatan, 2008.

Stevanus, Kalis. "Pelestarian Alam Sebagai Perwujudan Mandat Pembangunan: Suatu Kajian Etis-Teologis." KURIOS: Jurnal Teologi dan Pendidikan Agama Kristen 5, no. 2 (2019): 94-108.

Sulistyowati, Endah. Implementasi Kurikulum Pendidikan Karakter. Yogyakarta: Citra Aji Parama, 2012.

Woi, Amatus. Menyapa Bumi Menyembah Hyang Ilahi, Dalam Buku "Manusia Dan Lingkungan Dalam Persekutuan Ciptaan." Yogyakarta: Kanisius, 2008. 